Бобан Ћурић

Универзитет у Београду Филолошки факултет

Катедра за славистику

boban.curic@sbb.rs
УДК 314.73(=161.1)(497.11) https://doi.org/10.18485/slavistika.2018.22.2.18 оригинални научни рад примљено 13.02.2018. прихваћено за штампу 04.10.2018.

\title{
ГОСТОВАЮА Ј. Н. ЧИРИКОВА У БЕОГРАДУ 1928. И 1929. ГОДИНЕ
}

J. Н. Чириков посетио је Београд два пута: у септембру 1928. године као учесник конгреса руских књижевника и новинара у емиграцији и у новембру 1929. године на позив Руског научног института. Београдској публици руски писац представио се на књижевним вечерима и јавним наступима, кроз интервјуе и ауторске текстове, објављење на страницама београдске периодике.

Кључне речи: Јевгениј Николајевич Чириков, Београд, руска емиграција, руска књижевност.

Evgeny Nikolayevich Chirikov visited Belgrade twice: in September of 1928 as a participant of the Congress of Russian writers and journalists in emigration and in November of 1929 as a guest of the Russian Scientific Institute. He presented himself to the Belgrade public at literary evenings and public events and through interviews and articles published in Belgrade periodicals.

Key words: Evgeny Nikolayevich Chirikov, Belgrade, Russian emigration, Russian literature.

Веза с Београдом Јевгенија Николајевича Чирикова (1864-1932), руског писца и публицисте који је своју популарност и књижевну славу стекао почетком XX века, заправо је успостављена већ на самом почетку његовог принудног изгнанства из постоктобарске Русије. Како је више пута истицао, он није добровољно отишао из земље, већ је из ње био протеран. Наиме, када му је 1918. године Лењин посаветовао да напусти Русију, претећи му хапшењем уколико одбије, Чириков је са супругом отишао на југ, прво у Ростов на Дону, а затим на Крим, последњи бастион антибољшевичке борбе. После евакуације Крима, у новембру 1920. прелази у Константинопољ, почетком 1921. у Софију, да би на позив чехословачке владе, у септембру 1921. године, преко Београда отишао бродом до Братиславе, па оданде возом до Прага, у коме ће провести преостале „емигрантске“ године свога живота. У музеју Ј. Н. Чирикова у месту Городец поред Њижњег Новгорода (о коме се брну пишчеви потомци, његова унука Валентина и његов праунук Михаил) чувају се наочаре које је Јевгениј Николајевич тада купио у Београду.

У Чехословачкој Чириков наставља живу стваралачку делатност. Уз Василија Немировича-Данченка постаје једна од најзначајнијих и најактивнијих фигура прашког Савеза руских књижевника и новинара у емиграцији. Као члан прашке делегације Савеза, Чириков ће узети учешћа и у раду београдског конгреса руских књижевника и новинара у емиграцији, у јесен 1928. године (Аноним 1928a; Аноним 1928b).

Чириков у Београд стиже 22. септембра и одмах привлачи пажњу новинара (Аноним 1928c). Сутрадан по доласку у Правди је освануо подужи интервју

\footnotetext{
* Овај рад настао је у оквиру пројекта 178003 („Књижевност и визуелне уметности: рускосрпски дијалог“) који финансира Министарство просвете и науке Републике Србије.
} 
са руским писцем (Аноним 1928d). Представљајући књижевно стваралаштво Јевгенија Николајевича, непознати новинар подвлачи традицију руског реализма коју писац наставља, „дајући лепе обрасце деликатних психолошких анализа, приказујући руски живот широко и са дубоким разумевањем унутрашњих особина његових“. На питање какви су услови за рад руских писаца у емиграцији, Чириков одговара: „Одмах морам нагласити да ми живимо под веома тешким околностима за рад. Чак и они познатији писци, који имају већ утврђену књижевну репутацију, морају да се боре са низом тешкоћа материјалне природе“. Руска емиграција, истиче писац, прилично је сиромашна, није у стању да купује књиге, у великој мери не може да задовољи ни оне најосновније животне потребе. Књиге се штампају у ограниченом тиражу (белетристика у просеку хиљаду и по до две хиљаде примерака), и тиме постају још скупље: „Велике књиге уопште се нерадо примају, јер су у продаји скупе и стога ризикују да остану без прође. Ја сам ту скоро, на пример, био у преговорима са једном руском издавачком књижаром у Паризу за издавање књиге мојих новијих приповедака. Ове су приповетке и издате, али подељене у две књиге: предузеће је страховало да велика, а према томе и скупа књига не остане без прође. ${ }^{1}$ Ја сам све ове моје приповетке замишљао као органску целину, али сам се морао помирити са оним што је неизбежно“. Писац се осврнуо и на свој књижевни рад. Узгред поменувши повести Црвени пајаи (Красный паяи, 1922) и Опустошена душа (Опустошенная душа, 1921), он се задржао на својим најновијим делима - Мој роман (Мой роман. Записки бежениа, 1927), Звер из бездана (Зверь из бездны, 1926; у Правди назван Звер из дубине) и Очев дом (Отчий дом, 1929-1931): „У Моме роману сам покушао да дам слике руског живота у току последњих година, а нарочито слике емигрантског живота. Сем овог дела, које је на руском издато у Паризу, написао сам још један роман Звер из дубине. У овом делу бавим се психологијом грађанског рата у Русији. Летос сам писао, живећи у једном мирном и патријархалном месту Прикарпатске Русије велики роман Очев дом. Пишем га, у осталом, већ другу годину. Сем два поменута романа изашле су ми у оригиналу две књиге приповедака, које сам већ поменуо: Девојачке сузе и Између неба и земље“. Веома топлим речима Чириков се изразио о младим писцима руске емиграције. Истакао је двојицу, који су са њим допутовали из Прага - Глеба Рубанова и Василија Фјодорова (Аноним 1928d).

Истог дана Чириков се, уз Василија Немировича-Данченка, представио и читаоцима Политике (Аноним 1928е). У интервјуу неименованом сараднику овог листа он је говорио о совјетској књижевности и совјетским писцима. Ове последње поделио је у две групе: у једној су пролетерски писци, и међу њима нема никога који би себи могао изборити трајније место у руској књижевности. Њихова заједничка карактеристика јесте да „служе парти $>\mathrm{j}>$ ској ствари и претварају белетристику у оруђе, пропаганду“. У другој групи налазе се писци који покушавају да остану на позицијама дореволуционарне „поштене“" књижевности. Иако не желе да служе званичној идеологији, приморани су да чине уступке захтевима цензуре. Њихова дела углавном су посвећена критици негативних страна совјетског живота. „Они нас одлично разумеју, као и

' У питању су приповедне збирке Девојачке сузе (Девичьи слезы) и Између неба и земье (Между небом и землей), објављене 1927.

Славистика XXII/2 (2018) 
ми њих“- примећује Чириков. Присећа се недавног сусрета са совјетском списатељицом Лидијом Сејфулином, у Прагу. Иако мисли да је искрена и да има талента, чини му се да „претерано верује у оно што је чула од бољшевика“. Зато њена дела која је читала чешким радницима (очигледно с циљем идеолошке пропаганде, иако руски писац то не говори), код њих нису изазвала никакве симпатије, јер су тематику ових дела оценили као преуску, једнострану и неинтересантну (Аноним 1928е).

Утисак који је Јевгениј Чириков остављао како на учеснике конгреса, тако и на новинаре и београдску публику, пренео је верно новинар Времена: „Г. Чириков одмах пада у очи својом дугачком седом косом и белом брадицом. Он је један од ретких књижевника, који је још остао веран старој традицији из Русије и бивших времена, када су сви књижевници и уметници носили дугачку косу. Остали су је одсекли и изгледају као обични људи. И сачувао је г. Чириков живахност покрета и мисли, свежину погледа и речи, тако да му нико не би дао његових пуних 70 година. Старији је неколико година од г. Мерешковског, а свако би на први поглед закључио потпуно обрнуто“ (Херенда 1928b).

Уочи отварања конгреса, руски писци представљени су подробно на првим страницама београдских дневника, у текстовима које су пропратиле фотографије учесника. Највећа пажња при том посвећена је Мерешковском и НемировичуДанченку, нешто мања Куприну, док су 3. Гипијус, Б. Зајцев и Н. Чириков често остајали у сенци горепоменутих „величина“ (тако ће, уосталом, бити и током читавог трајања конгреса). Лист Правда код Чирикова истиче уметнички снажну обраду социјалних мотива (Аноним 1928f), док Време и Политика подсећају на његове књижевне почетке у кругу сарадника алманаха „Знање“, као и на његово драмско стваралаштво и сарадњу с МХТ (посебно се помињу као најпопуларније драме Јевреји и Иван Миронич, 1904) (Херенда 1928а; Аноним (1928g). Од новијих књижевних дела, насталих у емиграцији, новинар Времена помиње иста она дела која је и руски писац навео у интервјуу Правдином сараднику: романе Звер из бездана (у Времену Звер из дубине) и Мој роман, приповедни зборник Девојачке сузе (у Времену погрешно назван Девојачко срие), као и рад на роману Очев дом (Херенда 1928a).

Како су делегације учесника пристизале у Београд, тако су се и њихове активности, које су пратиле рад конгреса, интензивирале. У просторијама домаћина конгреса, београдског Савеза руских књижевника и новинара, које су се тада налазиле у Скопљанској улици бр. 18 (данас је то Нушићева улица), 24. септембра обављено је фотографисање учесника. Међу присутнима налазио се и Чириков (Аноним 1928h).

Конгрес руских писаца и новинара у емиграцији свечано је отворен 25. септембра у 11 сати, у великој сали зграде Новог универзитета (данас зграда Филолошког факултета). У председништву свечане седнице седео је и Чириков: „За великом трибином заузео је председничко место уважени руски књижевник, осведочени словенофил и пријатељ нашега народа г. Василије Ивановић Немировић-Данченко. Десно од њега заузели су места редом: министар просвете г. Милан Грол, славни књижевник г. Мерешковски, председник београдске општине г. др. Коста Кумануди, ректор Београдског Универзитета г. др. Чеда Митровић, професор г. Боголепов, књижевник г. Борис Зајцев, г. 
Евгениј Чириков, г. Александар Јаблоновски. Лево од председникова места седели су: председник Савеза Руских Књижевника и Новинара у нашој замљи г. Алексије Ксјуњин, г-ђа Зинаида Хипиус, професор Београдског Универзитета г. др. Александар Белић, г. Евгениј Жуков, шеф париске групе учесника конгреса г. Владимир Зелер, епископ нишки г. Доситеј, књижевник г. Вељко Петровић“ (Аноним 1928i). ${ }^{2}$

Наредних дана конгрес је интензивно наставио свој рад. Бројна питања, важна за организовање и професионалну делатност у условима избеглиштва решавала су се на седницама затвореног типа, које су одржаване у слушаоницама Новог универзитета два пута дневно.

Основни циљ београдског конгреса био је да уједини и усклади заједничку активност свих руских културних сила у емиграцији, „срце и савест“ руску писце и новинаре. Људи од пера и слободне речи окупили су се како би целом свету објавили да храм руске културе можда јесте порушен, али не и уништен. По речима Чирикова, изговореним на банкету Савеза руских писаца и новинара у емиграцији, првог дана рада конгреса, културни посленици руске емиграције умногоме подсећају на житеље легендарног Китежа: „Да ли се сећате ви лепе приче о граду Китежу? За време татарске најезде на Русију није хтео Бог да допусти да Татари униште град Китеж. И створио је језеро, на чијем је дну Китеж, са својим становницима наставио да живи, одбрањен од Татара. И често је са дна допирало звоњење китешких звона. // Ми, руски књижевници и новинари у изгнанству, становници смо данас тог Китежа. А звоњење цркава наших то је победоносни ход наше културе. Да, господо, јер ми, побеђени, ипак побеђујемо. А језеро из старе легенде то су за нас данас словенски народи“" (Е. 3. 1928a).

Краљ Александар Карађорђевић примио је учеснике конгреса два пута: 27. септембра краљу је представљено свих 111 учесника конгреса (На страже России 1935: 66), а два дана касније у Двору је приређен интимни ручак у част председништва конгреса. Занимљиво је да ни један наш лист међу присутнима не помиње Чирикова (Аноним 1928m; Аноним 1928n). Према тврђењу пишчевог праунука, Михаила Чирикова, који негује успомену на свог славног претка, Јевгениј Николајевич је ипак присуствовао на ручку, али је разлог његовог изостављања тај што је на путу ка Двору руски писац имао пех, пао је и исфлекао свој фрак, те је морао да се врати у хотелску собу и пресвуче у свечано одело. Зато и није стигао на регистрацију гостију.

Водећу улогу у радном делу конгреса имали су новинари и публицисти. Писци су били активнији на пратећим манифестацијама, јавним наступима и књижевним вечерима. Када је реч о Чирикову, бележимо његово присуство само на једној седници, другог дана рада конгреса, 26. септембра, на којој се расправљало можда о најважнијем проблему писаца у емиграцији - питању заштите ауторских права (Аноним 1928j).

Од бројних пратећих манифестација конгреса, бележимо Чириковљево појављивање на већ поменутом банкету Савеза руских књижевника и новинара у ресторану „Српски краљ“, 25. септембра (Е. 3. 1928a), затим на банкету министра просвете Милана Грола, 26. септембра у хотелу „Палас“ (Аноним 19280),

${ }^{2}$ Детаљније о конгресу руских књижевника и новинара види: Ћурић Б. (2011).

Славистика XXII/2 (2018) 
на чајанки Југословенског новинарског удружења у Новинарском дому, такође 26. септембра (Аноним 1928k), на соколској академији руског одсека Соколског друштва „Београд - Матица“, 28. септембра (Аноним 1928p), на свечаности у Дому Београдског женског друштва, 30. септембра. У топлом говору који је том приликом одржао, Чириков је глорификовао српску жену и њене успехе на свим пољима друштвеног живота (Е. 3. 1928b).

Јевгеније Николајевич је председавао и свечаном академијом, која је у организацији Савеза руских књижевника и новинара, а поводом стогодишњице рођења Лава Толстоја, одржана 26. септембра у великој сали Новог универзитета (Аноним 19281).

Треба истакнути свакако, наступе руских писаца на књижевним вечерима. Тако је 30. септембра одржано вече у великој сали Новог универзитета, када су пред одушевљеном публиком наступили Василиј Немирович-Данченко, Јевгениј Чириков, Зинаида Гипијус, Дмитриј Мерешковски, Александар Куприн, Борис Зајцев и Александар Јаблоновски (Аноним 1928q). Чириков је тада прочитао своју приповетку Снежана (Снегурочка, 1923). У истој сали Новог универзитета на књижевној вечери 6. октобра наступили су Куприн, Зајцев и Чириков (Аноним 1928t), а два дана касније, 8. октобра, на затвореној седници (тзв. интимное собрание) Савеза руских књижевника и новинара, Чириков је наступио још једном, овога пута пред београдском руском публиком. Није, међутим, до краја јасно шта је било на програму овог књижевног наступа. Док се у јубиларној публикацији Савеза поводом десетогодишњице рада помиње читање приповедака (На страже России 1935: 29), лист Време пише како је Чириков овом приликом прочитао „своју нову трагедију“ (не наводи се коју конкретно!) и да се после читања о њој развила дискусија у којој су учествовали Алексеј Ксјуњин, Јуриј Ракитин, Фјодор Тарановски, Василиј Глуздовски и други чланови Савеза (Аноним 1928u).

На књижевној вечери 30. септембра прочитан је краљев указ о одликовању руских писаца и новинара орденом Светог Саве. Василиј Немирович-Данченко и Дмитриј Мерешковски одликовани су орденом Светог Саве првог реда, док су Зинаида Гипијус, Александар Куприн, Борис Зајцев и Јевгениј Чириков одликовани орденом Светог Саве другог реда (Аноним 1928r).

Конгрес је завршен 1. октобра, свечаном седницом на Новом универзитету.

По завршетку рада конгреса, попут многих других руских писаца, ни Јевгениј Чириков није одмах напустио нашу земљу. Са осталим учесницима посетио је 1. октобра болницу Руског црвеног крста у Панчеву (Аноним 1928s), а потом је, заједно са Борисом Зајцевом кренуо у обилазак руских школа у унутрашњости земље (Е. 3. 1928c). У Сарајеву је одржао једно предавање, а затим посетио тамошњи руски кадетски корпус, ${ }^{3}$ одржао књижевно вече и упознао се с литерарним стваралаштвом питомаца (Аноним 1928v). Пре повратка у Праг посетио је још и Љубљану, где је на позив Руске матице одржао још једно своје књижевно вече (Аноним 1928w).

${ }^{3}$ Први руски кадетски корпус великог кнеза Константина Константиновича, основан 1920. године, налазио се у Сарајеву до 1929, када је припојен Кримском кадетском корпусу у Белој Цркви. 
Одушевљен указаним почастима и пријемом код београдске публике, Чириков се радо одазвао позиву новооснованог Руског научног института да врло брзо, већ следеће године поново дође у Београд. Иако се у штампи његов долазак најављивао већ за пролеће 1929. године (Аноним 1928v), из писма које је почетком априла 1929. Јевгениј Николајевич послао Александру Белићу, сазнајемо како је председник Института, Јевгениј Спекторски, Чирикову предложио јун као термин за гостовање, што је, по мишљењу руског писца, погрешно време, јер публике за планиране јавне наступе у то време неће бити. Из истог писма сазнајемо и оквирни план активности за време нове посете: „(..) хочется поставить свою пьесу, устроить „Волжский вечер“. Прочитать думаю о Горьком, Андрееве и отрывки из своих воспоминаний литер<атурно> - обществен<ного> характера. Пожалуй, что в месяц всего этого не успеешь сделать. Но хочется иметь публику, а не пустой зал, что непременно случится летом. Я рассчитывал на весну - апрель, май. Но раз этого не вышло, то уж лучше сделать осенью или совсем не делать“ (Чириков - Беличу 2016а).

Из писма које је Чириков крајем октобра 1929. послао Белићу, сазнајемо и теме предложених предавања: 1 . Леонид Андрејев и Максим Горки као знамеьа времена; 2. На путевима живота и стваралаштва - одломци из успомена; 3. Мајмунско огледало. - Еволуција морала интелигенције. Потврђује се вече посвећено Волги, у организацији Савеза руских књижевника и новинара, а предлаже се и могућност држања још једног предавања, у Савезу, под насловом „Каријера М. Горког“ (Чириков - Беличу 2016b). Београдска периодика која у јесен 1929. пише о Чириковљевом доласку, помиње држање предавања, али без указивања њихове тематике (Драинац 1929).

Изгледа да су Чириковљеви разлози на крају уверили руководство Института да руског писца позове крајем јесени. Чириков је у Београд стигао 19. новембра 1929. (Аноним 1929a; Аноним 1929b). Са њим је дошла и његова ћерка, госпођа Херинг као лични секретар. „Стари познаник Београда“ (Аноним 1928а) одмах по доласку привукао је пажњу престоничке штампе. Већ 22. новембра појавила су се два интервјуа која је руски писац по свом доласку дао новинарима листова Правда и Време (Драинац 1929; Глуздовски 1929).

Сарадник листа Правда, песник и публициста Раде Драинац, посетио је Чирикова одмах по доласку у Београд и са њим водио интересантан разговор (Драинац 1929). Чириков је, као и увек, говорио искључиво на руском, а његова ћерка оживљавала је својим примедбама на француском конверзацију, која се понекад водила отежано због Драинчевог непознавања руског. Напис у Правди отвара Чириковљев портрет: „типично словенски, благи човек, са сребрном косом и ведрим осмехом“. Сарадник Правде истиче искрену и дубоку љубав Чирикова према Београду, те наводи његове речи да Београд у њему буди успомене на напуштену домовину: „Долазим у Београд да блискије оживим сећање на Волгу, гледајући овај плави, поетични Дунав, суморно умотан јесењом маглом и облацима“. Успомене на Волгу побудиле су и прво Драинчево питање - о почецима књижевне каријере, везане управо за Волгу. „Живео сам на Волги, <y> Казану“, присећа се руски писац, „и ту, наравно, започео сам и прву литерарну каријеру кроз новине и часописе. Данас је равно 43 године како радим, а написао сам толико, да се више и не сећам свих 
дела...“. Јевгениј Николајевич има у виду 1886. годину, када је у казањском листу Волжский вестник објављен његов књижевни првенац, приповетка Риђи (Рыжий). Чириков даље истиче сарадњу с петербуршким часописима Русское богатство и Мир Божсий, који су му донели популарност широм Русије; говори о блискости с „народњачком“ струјом у руској књижевности, окупљеној око критичара Михајловског, о Горком и групи писаца окупљеној око алманаха „Знање“. У сопственом књижевном стваралаштву издваја трилогију Младост (Юность, 1911), Прогонство (Изгнание, 1913) и Повратак (Возвращение, 1914). Трилогија, у великој мери аутобиографична, носи наслов Живот Тараханова (Жизнь Тараханова) који се у Правдином напису не помиње. У емиграцији ће настати и четврти део, који носи наслов Породича (Семья, 1925), али и он ће остати изван видокруга Правдиног текста. Руски писац такође истиче приповетку Ропство човечанских страсти (Плен страстей человеческих, 1910) и романе Очев дом и Звер из бездана. Не заборавља ни драмско стваралаштво, иако не помиње ни један комад поименице.

И опет - питање о совјетској књижевности. За разлику од многих других припадника руске емиграције, који су одрицали било какве квалитете совјетској књижевности, Чириков о њој није имао изразито негативно мишљење: „Има тамо дивних талената. Они су сви у водама уметничког реализма наших прошлих дана. Али, они живе под чудним околностима. Цензура им гуши сваку слободну мисао. Видећемо шта ће се развити од њих. Мени лично много се допадају Леонов, Булгаков и Феђин“ (Драинац 1929).

Подробније о књижевности у совјетској Русији Чириков говори у разговору с новинаром листа Време, Василијем Глуздовским (Глуздовски 1929). Заправо, он је у том разговору изнео неке битне разлике између два тока руске књижевности, совјетске и емигрантске који, по њему, „иду паралелно и готово упоредо“. Констатујући како су у последње време у свету „идеали пали и продају се јевтино на берзи рада и живота човека“, Чириков примећује да је и књижевност у целини „пала с високог пиједестала“ и све више се банализује, под утицајем времена, рата, револуција, меркантилизма. Потискивана од филма и радија, књига је престала да буде Јеванђење за младог човека. Писци руске емиграције у таквим околностима углавном настављају да пишу у духу и традицији сопственог дореволуционарног стваралаштва: ,jа бих рекао да се они користе старом резервом“". Млади емигрантски писци су ретки; иако међу младима има веома добрих писаца (нико поименице није наведен), услед материјалних неприлика штампање њихових књига веома је ретко.

Истом стазом „такозваног уметничког реализма“ иду и савремени совјетски писци, одустајући од простог фотографисања живота, све више се окрећући класицима руског књижевног реализма. Модернистичке тенденције у совјетској књижевности све су ређе, што Чириков илуструје, чини нам се, прилично спорним примером стваралаштва Лава Лунца: „Један од најизразитијих представника модернизма, Лунц и сам прилази реализму“. Истиче књижевни таленат Булгакова и Катајева. На примедбу новинара да се у стваралаштву Катајева осећа велики утицај Гогоља, Чириков подвлачи да Гогољево стваралаштво има велики утицај на совјетску књижевност, посебно његова сатира, јер „негативне 
појаве живота налазе себе у творевинама нових писаца“. ${ }^{4}$ Када говори о певодима својих дела на друге језике (чешки, француски, шведски, норвешки, бугарски, пољски), писац не пропушта прилику да скрене пажњу на непоштовање ауторских права: „Преведено је доста и на српски, али, на жалост, података о томе, као и хонорара нема“" (Глуздовски 1929).

Једна од првих Чириковљевих активности по доласку у Београд било је председавање годишњом скупштином београдског Савеза руских књижевника и новинара, чији је почасни члан постао 23. децембра 1928. године (На страже России 1935: 52). Годишња скупштина је одржана 24. новембра у просторијама Савеза (Хиландарска 14). У поздравном говору, којим је отворио скуп, Чириков је подвукао значај књижевности и штампе у животу једног народа. Совјетска штампа, по њему, јесте само „грамофон комунистичке странке“ (Аноним 1929 c). Новој, од бољшевика ослобођеној Русији биће од велике користи руски писци и новинари који у изгнанству чувају дух слободе и истине. „Ми смо изгубили нашу отаџбину“, рекао је, између осталог, руски писац, „није лак нити је леп наш живот, али ми носимо ту Отаџбину у своме срцу, ми волимо њу, и у име те љубави настављамо наш посао. (...) Ми смо изгубили много, али смо сачували слободу савести и слободу наших убеђења“. Велики број књига, листова и часописа који се објављује у совјетској Русији не служи, по мишљењу Чирикова, за просветљавање људи, већ за помрачивање њихове свести. Братска Југославија, својом несебичном помоћи пружила је могућност руским писцима и новинарима да наставе свој позив све до тренутка, који није далек, када ће их ослобођена Русија позвати да својим слободним пером служе своме народу (Аноним 1929d). На предлог Чирикова послат је поздравни телеграм краљу Александру Карађорђевићу, заштитнику и покровитељу руских писаца и новинара у егзилу (Аноним 1929с; Аноним 1929d).

Београдски Савез руских књижевника и новинара организовао је 7. децембра у уметничком павиљону „Цвијета Зузорић“ на Калемегдану забавно вече под називом „Бела ноћ. Велики бал - концерт - кабаре“, на коме су учешће узели многи престонички руски и српски уметници. Поздравним говором том приликом публику је дочекао и вече отворио Ј. Чириков (Аноним 1929е).

Иако је приликом Чириковљевог доласка у штампи најављивано како ће познати руски писац у Београду држати циклус предавања на Руском научном институту, организатору и домаћину посете (Аноним 1929а; Драинац 1929), сама предавања остала су некако изван видокруга јавности. Није чак ни потпуно јасно да ли су предавања уопште одржана, као ни колико их је, заправо, било. Занимљиво је да дугогодишњи председник Руског научног института, Јевгениј Спекторски, у прегледу десетогодишњег рада Института не помиње никакво Чириковљево јавно иступање на Институту у зиму 1929. године (Спекторский 1939). Тек узгредно он Чирикова помиње само међу писцима који су по позиву Института боравили у Београду (Спекторский 1939: 10). У поименичном представљању делатности чланова Института, његов потоњи председник, Фјодор Тарановски, бележи само једно предавање на Институту, под насловом „На путях жизни и творчества - из воспоминаний“, одржано 15. децем-

${ }^{4}$ Очигледна је Чириковљева усмереност на критичко-сатиричну линију совјетске књижевности, док она друга, идеолошки афирмативна, не заслужује ни да буде поменута. 
бра 1929. године (Тарановский 1935). Сам податак, међутим, у најмању руку изазива чуђење, јер на основу других поузданих извора (ондашња периодика), Чириков је управо тог дана, 15. децембра, у Загребу држао предавање о Волги (Аноним 1929f; Аноним 1929g; Аноним 1929h). Постоји могућност да је ово предавање одржано, али неког другог дана, односно да је датум предавања погрешно наведен.

Београдска периодика најављује само Чириковљево предавање у Љубљани под насловом „Лепа књижевност као огледало живота и писци као обележје времена“ (Аноним 1929g). Као термин овог предавања лист Политика наводи 13. децембар, пре загребачке вечери посвећене реци Волги (одржане, подсетимо, 15. децембра), док лист Време љубљанско предавање под насловом „Књижевност као огледало живота и књижевници као представници доба“"5 смешта после загребачког наступа (Аноним 1929f).

Књижевно-уметничко вече, посвећено реци Волги, у организацији београдског Савеза руских књижевника и новинара, одржано је 20. децембра у великој сали Новог универзитета. „Песник Волге“, како су га у београдској штампи називали (Аноним 1929g; Аноним 1929k), родио се и одрастао на Волги; на њеним обалама провео је велики део свога живота. Живео је у Казању, Њижњем Новгороду, Царицину, Астрахању, Самари - градовима на Волги. На обалама реке која је у свести руског народа синоним за национални идентитет, рађале су се литерарне идеје и настајале бајке, легенде, предања. Најављујући београдско вече, неименовани Политикин новинар пише: „Г. Јевгеније Чириков је прави руски писац који заноси, одушевљава дубином својих сижеа, осваја финим схватањем природе, чаробном лепотом својих типова и слика. И до сада све до данас, поред тежина свега преживљеног, Чириков је сачувао необичну бодрост, веру и љубав према човеку. И исту ватрену љубав према свему руском и пре свега према својој непрегледној лепотици Волги““(Аноним 1929і).

Чириковљев наступ започео је излагањем о улози и значају велике реке у руској историји, као и у свести руског народа. На обалама ове реке, рекао је, између осталог, Чириков, „ишла је својим корацима наша историја, остављајући безбројне трагове своје“. Са Волге су долазили највећи разбојници руског народа, али и његови спасиоци. Волга је дала државнике, сликаре, уметнике, научнике, писце. „Са Волге ће поћи ваљда и онај народни талас“, закључује своје уводно излагање руски писац, „које ће збрисати са руске земље њене садање гробаре“ (Аноним 1929k). Пред препуном салом Чириков је прочитао и неке своје приповетке, инспирисане фолклорним предањима и легендама сакупљеним за време скитања дуж Волге - Невидљиви храм (Храм незримый), Водена ияариияа (Царииа-водяница), Света гора (Святая гора) (Аноним 1929i). Напоменимо да су ово приповетке из зборника Бајке са Волге (Волжские сказки), објављеног 1916. у Москви. Наступ је био илустрован и пројекцијама слика познатих руских сликара - Кустодијева, Репина, Васњецова, Нестерова, Левитана, које су за тему имале пејзаже, градове, манастире, историјска места са обала велике руске реке. Музичком пратњом, извођењем песама са Волге, вече је употпунило Руско певачко друштво београдске Вазнесенске цркве, под управом диригента

${ }^{5}$ Незнатне разлике у преводу настале су вероватно услед тога што је изворник дат на руском језику. 
Алексеја Грињкова (Аноним 1929g). Вече је завршено изразима захвалности које је Чириков упутио „братском југословенском народу“ за помоћ и подршку Русима у изгнанству.

Пре но што ће се крајем децембра 1929. вратити у Праг, Чириков је посетио и руске школе у Белој Цркви, Великој Кикинди и Осјеку и у њима одржао предавања за ђаке о руској књижевности (Аноним 1929g).

Крајем децембра те 1929. године, као и више пута до тада, у Београду је гостовала прашка трупа художественика (Аноним 1929j). Тим поводом Политика је дала прилику Чирикову да на страницама овог листа изнесе своје импресије о чувеном московском позоришту с којим је тесно и сам сарађивао пре револуције. Ауторски текст „Поводом доласка Московског художественог театра“, објављен у Политици 22. децембра, само дан пре прве представе трупе художественика на сцени београдског Народног позоришта, говорио је о променама које је у позориште унео Художествени театар. Напомињући како га је гледање представе художественика подстакло да се и сам окуша у драмском стваралаштву, Чириков истиче самосвојност и оригиналност нове позоришне концепције. Подвлачи велику важност коју у новој концепцији добија аутор; писци драмског текста више нису „појединачни и случајни гости на позорници“. Даље пише: „Уметничка виртуозност Художественог Театра, која је ставила за свој задатак хармонично сливање аутора, глумца и уметника кичице, створила је, најзад, чудо позоришног дејства: свака режија постала је књижевно-уметничко стварање, у коме нема ни главних ни споредних лица“. У позориште се више није ишло како би се дивило глумцу у овој или оној улози, већ да се гледа и слуша позоришни комад. Захваљујући Художественом, нема више никаквих материјалних преграда између гледаоца и акције на сцени, наставља Чириков, опчињен „илузијом реалне истине коју су глумци персонифицирали у сваком свом кораку на позорници, свакој интонацији, мимици, гесту...“. На крају текста Чириков осуђује насиље над уметношћу у совјетској Русији и наметање некакве „класне тачке гледишта“. Утолико је значајније постојање оног дела Художественог театра, које се и даље у емиграцији залаже за висок ниво слободног уметничког стварања: „Судбина се смилостивила над опљачканом Русијом и оставила јој мило лице старог художественог театра, у омладини која продужује и у изгнанству да иде стопама својих старих оснивача и инспиратора овог националног класичног руског позоришта, да би донела заставу своје уметности до Русије ослобођење од свих насиља, и продужила у њој покидано грубом руком и грубом душом - позоришно стварање“ (Чириков 1929).

Када се почетком 1931. године Чириковљево здравствено стање погоршало, и када је промена климатских услова постала неопходна, Јевгениј Николајевич са супругом и унуком Валентином (Гуљом) поново долази у Југославију, прво у Љубљану средином априла, где је у то време живела са мужем његова ћерка Валентина, а потом на острво Вис, у мало рибарско село Комижу. На обали Јадрана остаће до средине јула, али овога пута, вероватно из здравствених разлога, до нове посете Београду неће доћи.

Живо сећање на Јевгенија Николајевича одржаваће у југословенској престоници његова дела, која су на руском објављивана у оквиру београдске Издавачке 
комисије (Издательская комиссия) и њене едиције „Руска библиотека“ (Русская библиотека). Породична хроника Очев дом (Отчий дом) изашао је у пет томова од 1929. до 1931. године, као 3, 4, 16, 29. и 30. књига „Руске библиотеке“ (књиге 1 и 2 - 1929, књига 3 - 1930, књиге 4 и 5 - 1931). Пред саму смрт Чириковљеву, као 35. књига едиције „Руска библиотека“ изашао је из штампе и приповедни зборник Вечерња звоњава (Вечерний звон). Остарели писац је предосећао да је ово његово последње дело. У писму које 5. марта 1931. године из Прага пише ћерки Људмили и зету Борису Шнитникову у Њујорк, читамо: „На очереди в Белградском издательстве книга моих повестей, последних, „Вечерний звон“, выйдет к осени. Пора уже кончать с писательством... возможно, что этим „Вечерним звоном“ и закончу дело. У меня вся жизнь моя выложена в книгах. Настоящее как-то отскакивает, будущего нет, прошлое исчерпано“ (Чириков - Шнитниковым 1931). На свом првом примерку књиге Чириков је уз наслов Вечерний звон дописао руком: „утонувшего колокола“.

Када је 18. јануара 1932. године Јевгениј Николајевич у Прагу умро, три најзначајнија београдска листа некролозима су се опростила од великог руског писца (3. 1932; Аноним 1932; Ксјуњин 1932). Издвајамо некролог Алексеја Ксјуњина, председника београдског Савеза руских књижевника и новинара у емиграцији, објављен у Политищи. Посветивши цео некролог драмском стваралаштву „великог руског писца и по својој доброти и срдачности необичног човека“, Ксјуњин заправо још једном даје реч самом Чирикову, преносећи његове успомене на прве кораке као драмског писца. Некролог симболично завршава следећим речима: „Представа је завршена. Завеса живота Чирикова је спуштена. Венци пријатеља ће прекрити у туђини гроб правог руског писца, честитог идеалисте и сјајног човека“ (Ксјуњин 1932).

Име Јевгенија Николајевича Чирикова и његово стваралаштво прекриће ускоро вишедеценијски принудни заборав, условљен, пре свега, идеолошким разлозима. У културну свест руског народа вратиће се тек после пада совјетског система 90-х година XX века. Овај рад видимо као покушај да се незаслужено заборављени аутор врати и у културну свест наше средине, за коју су га везивале чврсте, искрене и дубоке везе.

\section{Цитирана литература}

Аноним. , Конгрес руских књижевника и новинара у Београду“. Политика, 25. август 1928а: 6 .

Аноним. „Пред конгресом руских књижевника и новинара“. Политика, 6. септембар 1928b: 11.

Аноним. „Василије Немировић-Данченко у Београду“. Политика, 22. септембар 1928c: 6.

Аноним. „Г. Јевгениј Чириков у Београду“. Правда, 23. септембар 1928d: 5.

Аноним. „Г. В. Немировић-Данченко о Словенству и Русији. Г. Чириков о својој књижевности“. Политика, 23. септембар 1928е: 6.

Аноним. „Руски књижевници“. Правда, 25. септембар 1928f: 2.

Аноним. „Руски књижевници и новинари у Београду. Ко је све дошао на конгрес““. Политика, 25. септембар1928g: 7. 
Аноним. „Руски књижевници и новинари на гробу Незнаног јунака“. Правда, 25. септембар1928h: 2.

Аноним. „Срдачне манифестације руско-југословенског братства. Свечано отварање великог конгреса руских књижевника и новинара“. Правда, 26. септембар 1928і: 3.

Аноним. „Други дан конгреса руских књижевника и новинара. Питање ауторског права“. Правда, 27. септембар 1928j: 4.

Аноним. „Чај у новинарском дому“. Политика, 27. септембар1928k: 9.

Аноним. „Свечана академија у част Лава Толстоја“. Политика, 27. септембар 19281: 9.

Аноним. „Руски књижевници и новинари на интимном ручку у Двору“. Време, 30. септембар $1928 \mathrm{~m}: 5$.

Аноним. „Руски књижевници и новинари на ручку у Двору“. Политика, 30. септембар 1928n: 2.

Аноним. „Разговор са Мерешковским, великим мислиоцем и уметником“. Политика, 30. септембар 19280: 1.

Аноним. „Соколска академија у част руских писаца“. Правда, 30. септембар 1928p: 2.

Аноним. „Вече руских писаца“. Политика, 1. октобар 1928q: 4.

Аноним. „Вече руских писаца - Краљ је одликовао већи број учесника на конгресу - Говор г. Мерешковског“. Политика, 1. октобар 1928r: 4.

Аноним. „Руски књижевници у руској болници у Панчеву“. Политика, 2. октобар 1928s: 8.

Аноним. „Опроштајно вече А. И. Куприна“. Политика, 3. октобар 1928t: 9.

Аноним. „Одлазак г. В. И. Немировића-Данченка“. Време, 10. октобар 1928u: 5.

Аноним. „Руски писци путују по Југославији“. Политика, 11. октобар 1928v: 8.

Аноним. „Одлазак г.г. Немировича-Данченка и Чирикова“. Правда, 11. октобар 1928w: 10.

Аноним. „Долазак славног руског књижевника г. Чирикова“. Време, 18. новембар 1929a: 3.

Аноним. „Г. Евгеније Чириков у Београду“. Време, 20. новембар 1929b: 5.

Аноним. „Руски књижевници и новинари, са своје скупштине поздрављају Њ. В. Краља“. Време, 26. новембар1929с: 8.

Аноним. „Скупштина Савеза руских књижевника и новинара“. Политика, 26. новембар 1929d: 5.

Аноним. „Бал Бела ноћ“. Политика, 5. децембар 1929е: 5.

Аноним. „Г. Чириков у Загребу и Љубљани“. Време, 12. децембар 1929f: 7.

Аноним. „Волгино вече Ј. Н. Чирикова у Загребу и Београду“. Политика, 12. децембар 1929g: 14.

Аноним. „Предавање г. Чирикова у Загребу“. Правда, 16. децембар 1929h: 4.

Аноним. „На чаробном платну Русије“. Политика, 19. децембар 1929i: 7.

Аноним. „Репертоар Московских Художественика“. Политика, 19. децембар 1929j: 7.

Аноним. „Волга, Волга, моћ <sic!> роднаја“. Време, 21. децембар 1929k: 5.

Аноним. „Смрт великог руског књижевника Евгенија Чирикова“. Време, 20. јануар 1932: 4.

Глуздовски, Василиј. „Г. Евгеније Чириков о руској емигрантској и „совјетској“ књижевности“. Време, 22. новембар 1929: 5. 
Драинац, Раде. „Разговарајући са Евгенијем Чириковом...“. Правда, 22. новембар 1929: 2.

Е. 3. <Евгеније Захаров>. „Руски писци о српско-руској љубави“. Правда, 27. септембар 1928а: 5.

Е. 3. <Евгеније Захаров>. „Руски књижевници славе српску мајку“. Правда, 2. октобар 1928b: 5.

Е. 3. <Евгеније Захаров>. „Шта о нама пишу учесници конгреса руских писаца у својим листовима“". Правда, 6. октобар 1928c: 5.

3. <Захаров>. „Смрт Евгенија Чирикова“. Правда, 20. јануар 1932: 8.

На страже России. Десять лет Союза Русских Писалетелй и Журналистов в Югославии 1925-1935. Белград, 1935.

Ксјуњин, Алексеј. „Јевгеније Н. Чириков“. Политка, 20. јануар 1932: 9.

Спекторский, Е. В. «Десятилетие Русского научного института в Белграде (1928-1938)». Записки Русского научного института в Белграде 14, 1939: 3-27.

Тарановский, Ф. В. «Русский Научный Институт в Белграде за первые шесть лет его деятельности (с 1928/9 по 1933/4 акад. год включ.)». Записки Русского научного института в Белграде 11, 1935: 224.

Ћурић, Бобан. „Конгрес руских писаца и новинара у емиграцији и његово место у српској и руској култури“. Из живота руског Београда. Београд: Филолошки факултет, 2011: 39-62.

Херенда, А. Б. „Данас се у Београду отвара конгрес руских књижевника и новинара“. Време, 25. септембар 1928а: 5.

Херенда, А. Б. „Неколико дана међу великим руским књижевницима и новинарима“. Време, 3. октобар 1928b: 4.

Чириков - Беличу. Письмо Е. Н. Чирикова от 3 апреля, 1929: Ичин, Корнелия (ред.) От чужих к своим. Письма выдающихся представителей русской интеллигенции начала XX века Александру Беличу. Белград: Логос, 2016а: $48-51$.

Чириков - Беличу. Письмо Е. Н. Чирикова от 30 октября, 1929: Ичин, Корнелия (ред.) От чужих к своим. Письма выдающихся представителей русской интеллигенции начала XX века Александру Беличу. Белград: Логос, 2016b: 51.

Чириков, Јевгениј. „Поводом доласка Московског художественог театра“. Политика, 22. децембар 1929: 8.

Чириков - Шнитниковым. Письмо Е. Н. Чирикова к Шнитниковым из Праги в Нью Йорк от 5 марта, 1931. Семейный архив Е. Е. Чирикова, Минск 6.

${ }^{6}$ Податак добијен љубазношћу М. А. Чирикова. 
Бобан Чурич

\section{Е. Н. ЧИРИКОВ В БЕЛГРАДЕ В 1928 И 1929 ГОДУ}

\section{Резюме}

Е. Н. Чириков (1864-1932) два раза посетил Белград. В сентябре 1928 года принял участие в работе белградского съезда русских писателей и журналистов за рубежом. Съезд сопровождался литературными вечерами и публичными выступлениями писателей, на которых активное участие принимал и Чириков. В интервью белградским журналистам Евгений Николаевич высказывал свое мнение об условиях жизни и литературного творчества в эмиграции, о русской эмигрантской и советской литературе, о собственном литературном творчестве.

В ноябре 1929 года Чириков снова посетил Белград по приглашению Русского научного института. Внимание журналистов и белградской публики на этот раз привлек литературный вечер, посвященный реке Волге и ее роли в русской истории и в русской культуре.

Ключевые слова: Евгений Николаевич Чириков, Белград, русская эмиграция, русская литература. 